\title{
Analysis and Feasibility of Measures to Minimize the Impact of Acid Mine Waters Discharged by Abandoned Copper-Sulphide Mines on Hydrosphere of the Tagil River
}

\author{
Liudmila Ribnikova ${ }^{1,2}$, and Vera Navolokina ${ }^{1,2}$ \\ ${ }^{1}$ Ural State Mining University, 620144, Kuibyshev st., 30, Yekaterinburg, Russia \\ ${ }^{2}$ The Institute of Mining UB RAS, 620219, Mamin-Sibiryak st., 58, Ekaterinburg, Russia
}

\begin{abstract}
Mass closure of copper-sulphide mining sites both in the Sverdlovsk Region and worldwide resulted in the emergence of environmental challenges. One of such challenges is generation and discharge of acid mine waters. Manmade and natural factors have their impact on chemical composition of mine waters due to activation of sulphides oxidation processes taking place in disturbed rock mass and mines. Concentrations of components in treated mine waters are much higher than MAC (dozens and hundreds of times for iron, copper and zinc). That results in pollution of hydrosphere which goes on for decades and spreads over large distances along rivers. Quite a few reasons cause environmental degradation of hydrosphere in old industrial districts. These are baseline amounts of metals in the hydrosphere, low rates of selfrehabilitation of dead pits, high amounts of acid waters, high amounts of contaminants in mine waters, imperfection of treatment systems. Given the demand of mine waters treatment over decades, improvement of existing treatment systems and implementation of new technologies are required.
\end{abstract}

\section{Introduction}

Extraction of mineral resources, primary minerals processing followed by mine abandonment has been going on for thousands of years worldwide. That results in deterioration and partial exhaust of land, water and forest resources, deterioration of environment and some other environmental challenges.

Mining started in the Urals in the XVIII century and developed at very fast rates [1]. Copper-sulphide mines in the Middle Urals (the Sverdlovsk Region) were developed over the decades by both open-cut and underground mining methods. Most of those fields have been exhausted by now, the mines and mine sites are abandoned and flooded.

During the copper-sulphide field mining the top-slicing techniques of the mined-out space were used, which resulted in formation of holes, rock caving and shear zones at large areas reaching up to dozens and hundreds of hectares. Acid mine waters with high concentration of metals and low $\mathrm{pH}$ are generated as a result of natural weathering and anthropogenic activity. 
As the acid mine waters penetrate surface water bodies, they spread over hundreds of kilometers in relatively short time, decreasing acid condition and increasing the concentration of metals, thereby inflicting major damage to the hydrosphere and environment in general.

Abandoned copper-sulphide fields in the Sverdlovsk Region are the sites of accumulated environmental damage, where generation of the acid mine waters enriched with metals continues to this day. Thus, after abandonment of the Levikhinsky coppersulphide mine where production was underway for more than 70 years, and its flooding in 2003, as a result of rising of water level to natural level marks a risk of pollution of the land around the mine and surface water bodies by toxic mine and underspoil waters occurred. The main challenge at the mine remains discharge of insufficiently treated mine waters, enriched with copper, zinc and iron.

The goal of this study is analysis and feasibility of measures to minimize the impact of acid mine waters on hydrosphere of the Tagil river (the Sverdlovsk Region). In order to reach the specified goal, the following objectives were met: the data about impact of acid mine waters on hydrosphere were analyzed and generalized; composition of mine waters at Lomovsky, Karpushikhinsky and Levikhinsky copper-sulphide fields was studied, assessment of the impact of acid mine waters on Tagil river is presented; the measures to minimize the negative impact on the river hydrosphere were offered.

Global experience and case studies of implementation of measures to minimize the impact of acid mine waters. Active and passive methods are used to minimize the impact of acid mine waters. Application of active methods is connected with demand of uninterrupted drain water treatment operations using various process plants and agents. If the passive techniques are used, such operations are required at initial stages of treatment only, while only regular environmental monitoring is applicable throughout the entire process. The water treatment cost price and treatment efficiency make these approaches different (Table 1).

Table 1. Basic methods of treatment of acid mine waters and examples of their implementation

\begin{tabular}{|c|c|c|c|c|}
\hline Methods & Processes & $\begin{array}{l}\text { Avantages, } \\
\text { efficiency }\end{array}$ & $\begin{array}{l}\text { Application } \\
\text { limitations }\end{array}$ & $\begin{array}{l}\text { Application } \\
\text { examples }\end{array}$ \\
\hline \multicolumn{5}{|c|}{ Active treatment methods } \\
\hline Mechanical & $\begin{array}{l}\text { Treatment by } \\
\text { storage, } \\
\text { filtering, } \\
\text { Centrifuge } \\
\text { treatment }\end{array}$ & $\begin{array}{l}\text { Simple and cost- } \\
\text { effective } \\
\text { maintenance; } \\
\text { effective settling in } \\
\text { sediment ponds } 50- \\
62 \% \text {; decrease of } \\
\text { organic } \\
\text { contaminants } \\
\text { (TBOD) up to } 20- \\
25 \%\end{array}$ & $\begin{array}{l}\text { Occupy big areas. } \\
\text { Part of initial stage } \\
\text { of treatment process } \\
\text { for industrial } \\
\text { wastewater }\end{array}$ & $\begin{array}{l}\text { "Severonickel" } \\
\text { Copper and } \\
\text { Nickel Plant, } \\
\text { Russia, } 1967 \\
{[2]}\end{array}$ \\
\hline $\begin{array}{l}\text { Physical and } \\
\text { chemical }\end{array}$ & $\begin{array}{l}\text { Ion exchange, } \\
\text { treatment by } \\
\text { sorbents, } \\
\text { electrochemical } \\
\text { coagulation, } \\
\text { reverse osmosis, } \\
\text { ultrafiltration. }\end{array}$ & $\begin{array}{l}\text { Simple and compact } \\
\text { main equipment; } \\
\text { 90\% high degree of } \\
\text { treatment; no } \\
\text { demand in reagents; } \\
\text { treatment of high } \\
\text { wastewater } \\
\text { amounts; scrap } \\
\text { metal disposal } \\
\text { option; low energy } \\
\text { costs }\end{array}$ & $\begin{array}{l}\text { High capital } \\
\text { investments, no } \\
\text { selectability. High } \\
\text { costs of spent } \\
\text { regenerant solution } \\
\text { recycling }\end{array}$ & $\begin{array}{l}\text { Hongai coal } \\
\text { mine, Vietnam, } \\
2009 \text { [3] }\end{array}$ \\
\hline Chemical & Reagent & Doesn't demand & Implementation of & "Zapadnaya \\
\hline
\end{tabular}




\begin{tabular}{|c|c|c|c|c|}
\hline & $\begin{array}{l}\text { sedimentation, } \\
\text { coagulating, } \\
\text { flocculating, } \\
\text { reduction, } \\
\text { neutralization, } \\
\text { decontamination }\end{array}$ & $\begin{array}{l}\text { additional } \\
\text { structures; low cost, } \\
\text { effecive for drain } \\
\text { water deacidizing } \\
70-95 \% \text { and removal } \\
\text { of metals from drain } \\
\text { waters }\end{array}$ & $\begin{array}{l}\text { deacidizing demands } \\
\text { significant amounts } \\
\text { of lime and } \\
\text { construction of high } \\
\text { volume sludge } \\
\text { collectors }\end{array}$ & $\begin{array}{l}\text { Bis" Mine, } \\
\text { Russia, } 2004 \\
{[4]}\end{array}$ \\
\hline $\begin{array}{l}\text { Biological } \\
\text { (biochemical) }\end{array}$ & $\begin{array}{l}\text { biostimulation, } \\
\text { bioremediation }\end{array}$ & $\begin{array}{l}\text { Wastewater } \\
\text { purification from } \\
\text { sulfates and metals; } \\
\text { minimum reagents } \\
\text { applies; low energy } \\
\text { costs; using plants } \\
\text { for continuous } \\
\text { biotesting of treated } \\
\text { water quality }\end{array}$ & $\begin{array}{l}\text { Climate factor } \\
\text { limitations; biomass } \\
\text { adjustment to pure } \\
\text { substrates (hydrogen, } \\
\text { ethanol, methanol, } \\
\text { lactate et al), which } \\
\text { results in overall } \\
\text { development cost }\end{array}$ & $\begin{array}{l}\text { Caribou Zinc } \\
\text { mine, Canada, } \\
2001 \text { [5] }\end{array}$ \\
\hline \multicolumn{5}{|c|}{ Passive treatment methods } \\
\hline Biological & $\begin{array}{l}\text { Aerobic } \\
\text { anaerobic } \\
\text { wetlands; } \\
\text { Sulphate } \\
\text { reducing } \\
\text { bioreactors. }\end{array}$ & $\begin{array}{l}\text { Decontamination } \\
\text { efficiency for Fe } \\
0.13-96 \%, \mathrm{Al} 29- \\
56 \%, \mathrm{Mn} 76 \% \text {; low } \\
\text { operating expenses; } \\
\text { minimum power } \\
\text { consumption }\end{array}$ & $\begin{array}{l}\text { Decontamination } \\
\text { efficiency depends } \\
\text { on specific terrain } \\
\text { conditions; large } \\
\text { areas required for } \\
\text { arrangement of } \\
\text { treatment plants, } \\
\text { high amount of } \\
\text { sedimentation. } \\
\text { Specific water } \\
\text { flowrate needs to be } \\
\text { maintained. }\end{array}$ & $\begin{array}{l}\text { Wheal Jane } \\
\text { mine, UK, } 1994 \\
\text { [6]. } \\
\text { Lousal mine, } \\
\text { Portugal, 1995 } \\
\text { [7]. } \\
\text { Lacy-South, } \\
\text { mine, USA, } \\
2009 \text { [8] }\end{array}$ \\
\hline $\begin{array}{l}\text { Physical and } \\
\text { chemical } \\
\text { barriers }\end{array}$ & $\begin{array}{l}\text { Open and } \\
\text { oxygen-free lime } \\
\text { channels; } \\
\text { Continuous } \\
\text { alkalization } \\
\text { system }\end{array}$ & $\begin{array}{l}\text { Inexpensive primary } \\
\text { treatment stage of } \\
\text { mine waters. } \\
\text { Reagents refill every } \\
15-25 \text { years }\end{array}$ & $\begin{array}{l}\text { Very uncommon on } \\
\text { its own -different } \\
\text { geochemical activity } \\
\text { processes take place } \\
\text { with their formation } \\
\text { at various intensities, } \\
\text { forming complex } \\
\text { barriers; construction } \\
\text { is preferred on steep } \\
\text { slopes }\end{array}$ & $\begin{array}{l}\text { Howe Bridge } \\
\text { field, } \\
\text { USA, } 1992 \text { [9] } \\
\text { Unnamed mine, } \\
\text { the La Silva } \\
\text { River, Spain, } \\
\text { 2004 [10] } \\
\text { Deerplay mine, } \\
\text { UK, 2001 [11] }\end{array}$ \\
\hline
\end{tabular}

Survey area description. Lomovsky, Karpushikhinsky and Levikhinsky coppersulphide group of fields are located within Kirovgrad Urban District of the Sverdlovsk Region, in $16 \mathrm{~km}$ (Lomovsky mine), in $20 \mathrm{~km}$ (Karpushikhinsky mine) and in $30 \mathrm{~km}$ (Levikhinsky mine) to the north-west of Kirovgrad town, on the eastern edge of villages Lomovka, Karpushikha and Levikha, respectively. 


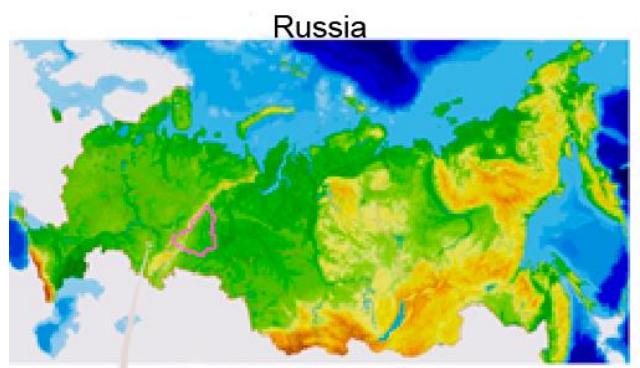

The Sverdlovsk Region

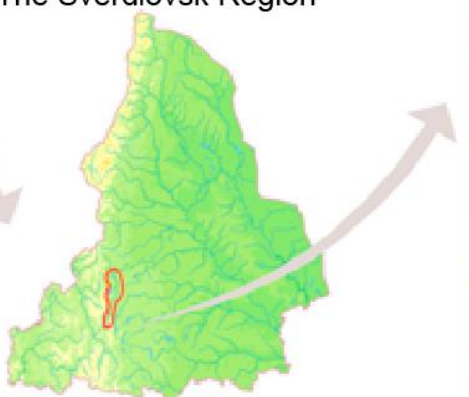

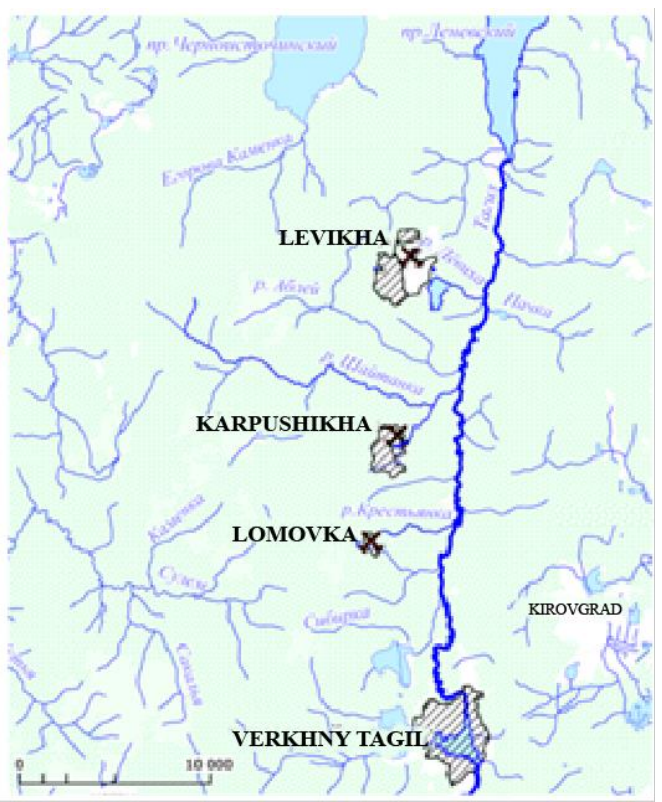

Fig. 1. Location scheme of the object (Upper Tagil River)

The hydrographic pattern of studied land is represented by the Tagil river and its left bank tributaries: Krestyanka, Shaytanka and Levikha rivers. The copper-sulphide mines and pits are mainly located around those rivers.

The Tagil river is a big river in the Sverdlovsk Region originating at the eastern slope of the Middle Urals, in the valley between the mountain Pereval and the mountain Karabay (Fig. 1). The river mainly flows in north-eastern direction and is a left bank tributary of the Tura river (falls within Irtysh basin area). The Tagil river is $414 \mathrm{~km}$ long, the flood basin is 10.1 thousand $\mathrm{km}^{2}$. 


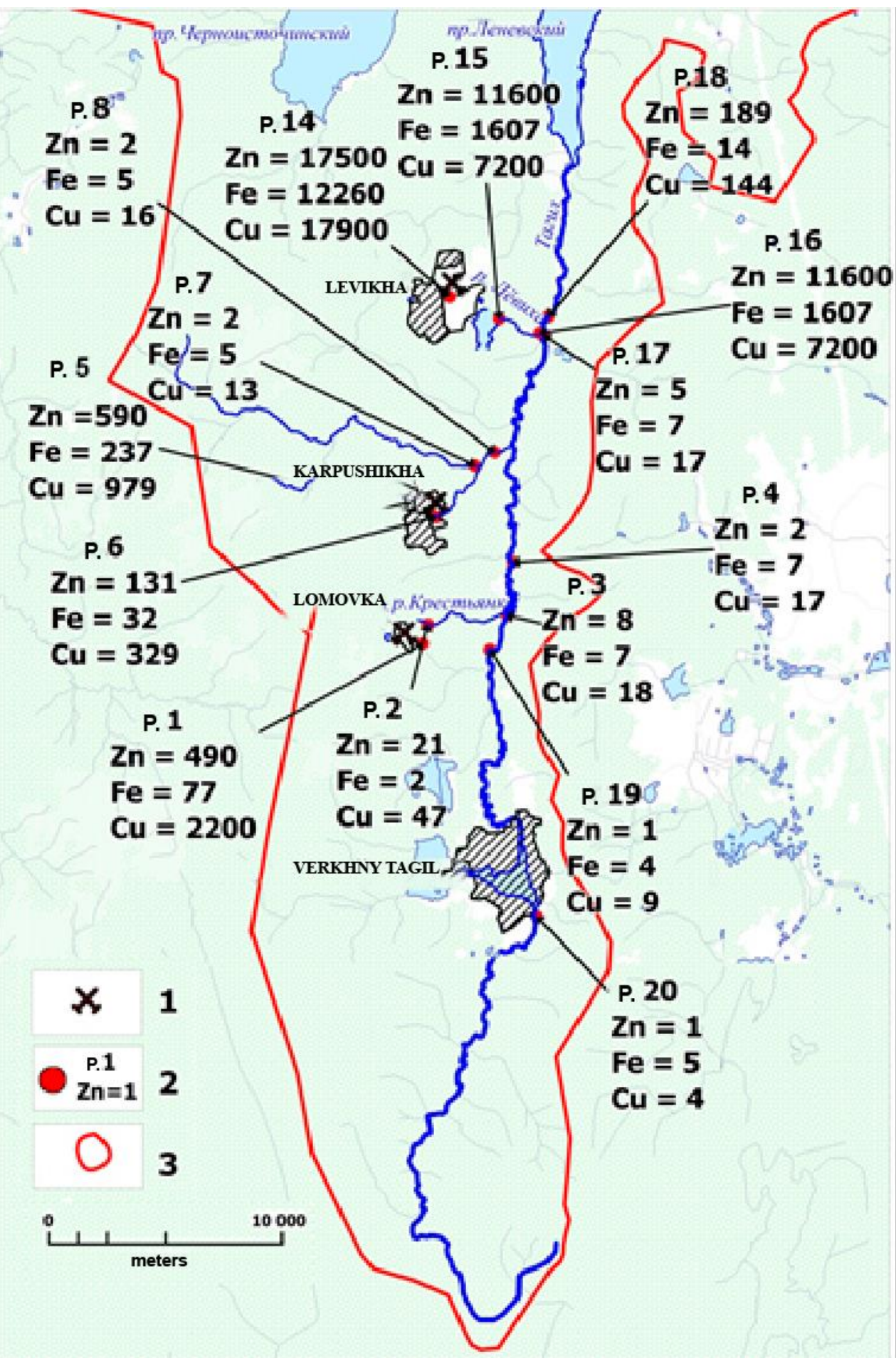

Fig. 2. Index map of upper reaches of the Tagil river basin. Legend: 1 - dead mines, 2 - sampling points and component-wise MAC overrun ratio for water bodies of commercial fishing importance, 3 -surface flood basin outline 
The copper-sulphide mines were developed by open-cut and subsurface carving methods. Huge areas of rock shear and rock fall with pot-holes formed within miny takes. Acid mineralized mine waters containing sulphates with high concentration of $\mathrm{Fe}, \mathrm{Al}, \mathrm{Mg}$, $\mathrm{Zn}, \mathrm{Cu}, \mathrm{Mn}$ [12] were generated as a result of production with decrease of ground water level. Elemental composition of acid mine waters released during production can be represented by Kurlov equation :

$$
M_{24,8} \frac{\mathrm{SO}_{4} 96}{A l 33 \mathrm{Mg} 23 \mathrm{Fe} 21 \mathrm{Ca} 10 \mathrm{Zn} 8} \mathrm{pH} 2,5
$$

After abandonment and flooding of copper-sulphide mines formation of acid mine waters did not stop, and as a result of water level increase the areas where mine waters were discharged to the surface were formed, which became a source of pollution of surface and ground waters (Table 2).

Table 2. Composition of mine waters in manmade water bodies at flooded copper-sulphide mines (as of 2019)

\begin{tabular}{|c|c|}
\hline Facility & Elemental composition of mine waters \\
\hline Lomovsky mine & 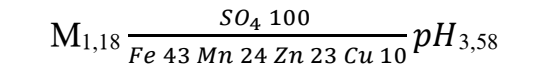 \\
\hline Karpushikhinsky mine & $\mathrm{M}_{0,7} \frac{\mathrm{SO}_{4} 100}{\mathrm{Fe} 77 \mathrm{Zn} 16 \mathrm{Mn} \mathrm{4Cu} 3} \mathrm{pH}_{3,64}$ \\
\hline Levikhinsky mine & $\mathrm{M}_{12,5} \frac{\mathrm{SO}_{4} 100}{\mathrm{Fe} 85 \mathrm{Zn} 10 \mathrm{Mn} \mathrm{4 \textrm {Cu } 1}} p H_{3,62}$ \\
\hline
\end{tabular}

To prevent pollution of environment acid mine water treatment plants utilizing milk of lime as reagent were set up at those facilities in the $70 \mathrm{~s}$ of the $20^{\text {th }}$ century. The treatment process includes water collection and water transfer from man made water tank, primary water neutralization, water precipitation in clarification pond and discharge to the Tagil river [13].

\section{Materials and methods}

From 2007 to the present mine waters composition within flooded Lomovsky, Karpushikhinsky, Levikhinsky copper-sulphide mines is monitored by the company performing mine waters neutralization. Most critical pollution indexes characterizing the acid mine waters are estimated daily: $\mathrm{pH}, \mathrm{Cu}^{2+}, \mathrm{Zn}^{2+}, \mathrm{Fe}_{\text {common }}, \mathrm{Mn}^{2+}, \mathrm{SO}_{4}{ }^{2-}$. Potentiometric, photometric and gravimetric methods are used for their analysis (Chemical Testing Laboratory of the branch of the National Public Institution "Ural Monazite", Levikha village).

In addition, the Tagil river downstream water was sampled starting from a cross section located above the town of Verkhny Tagil to determine background concentrations in October, 2019. Further sampling points were selected downstream the Tagil river in cross sections above and below discharge of treated acid mine waters from abandoned coppersulphide mines. The content of micro and macro elements in water was assessed by atomic emission and mass-spectral analysis techniques with inductively coupled plasma (Institute of Microelectronics Technology and High-Purity Materials, Russian Academy of Sciences). 


\section{Results and discussion}

The following regularities were identified during water analysis at flooded copper-sulphide fields. $\mathrm{pH}$ values are about 3.6 (Table 3), all waters generated in man made water tanks are acid waters. Starting from the upper reaches, the water in the Tagil river has $\mathrm{pH}$ value from 7.0 to 7.7 in spite of discharge of treated mine waters, wherein $\mathrm{pH}$ doesn't reach standard values; the water appears to be neutral after the discharge. The exceeding copper and iron MAC (by 2 and 5 times is already observed in upper reaches of the Tagil river, which is explained by natural pollution of the river, and since the river is flowing slowly and there is no sufficient time for its self-purification, it results in generation of polluted waters over the entire stretch of the river from the town of Verkhny Tagil to Lenevsky Pond.

Table 3. Concentration of components in the Tagil river at the stretch from the town of Verkhny Tagil to Lenevsky Pond (average values over 2019)

\begin{tabular}{|c|c|c|c|c|c|c|}
\hline \multirow{4}{*}{ Sampling location } & \multicolumn{6}{|c|}{ Values, mg/l } \\
\hline & $\mathrm{pH}$ & $\mathrm{Cu}^{2+}$ & $\mathrm{Zn}^{2+}$ & $\mathrm{Fe}_{\text {cjmmon }}$ & $\mathrm{Mn}^{2+}$ & $\mathrm{SO}_{4}{ }^{2+}$ \\
\hline & \multicolumn{6}{|c|}{ MAC(fisheries) [14] } \\
\hline & $6.5-8.5$ & 0.001 & 0.01 & 0.1 & 0.1 & 100 \\
\hline $\begin{array}{c}\text { point } 20 \\
\text { background Tagil } \\
\text { river }\end{array}$ & 7.3 & 0.004 & 0.01 & 0.5 & 0.03 & 18 \\
\hline $\begin{array}{c}\text { point } 19 . \text { Tagil } \\
\text { river, } \\
\text { downstream of } \\
\text { Verkhny Tagil }\end{array}$ & 7.0 & 0.009 & 0.01 & 0.4 & 0.1 & 38 \\
\hline \multicolumn{7}{|c|}{ Lomovsky mine } \\
\hline $\begin{array}{l}\text { point } 1 \text { Mine } \\
\text { waters }\end{array}$ & 3.6 & 2.15 & 4.96 & 7.7 & 6 & 825 \\
\hline $\begin{array}{c}\text { point } 2 \\
\text { Clarification pond }\end{array}$ & 7.7 & 0.05 & 0.21 & 0.2 & 0.3 & 360 \\
\hline $\begin{array}{l}\text { point } 3 \text {. Tagil } \\
\text { river, above } \\
\text { discharge } \\
\end{array}$ & 7.6 & 0.02 & 0.08 & 0.7 & 0.1 & 43 \\
\hline $\begin{array}{l}\text { point } 4 \text { Tagil river, } \\
\text { below discharge }\end{array}$ & 7.7 & 0.02 & $\mathbf{0 . 0 3}$ & 0.7 & 0.1 & 39 \\
\hline \multicolumn{7}{|c|}{ Karpushikhinsky mine } \\
\hline $\begin{array}{c}\text { point } 5 \text { mine } \\
\text { waters }\end{array}$ & 3.6 & 0.92 & 5.94 & 23.7 & 1.5 & 318 \\
\hline $\begin{array}{c}\text { point } 6 \text { mine } \\
\text { waters }\end{array}$ & 10.2 & 0.33 & 1.3 & 2.9 & 0.2 & 251 \\
\hline $\begin{array}{l}\text { point } 7 \text { Shaytanka } \\
\text { river, above } \\
\text { discharge }\end{array}$ & 7.3 & 0.01 & 0.02 & 0.4 & 0.02 & 7 \\
\hline $\begin{array}{l}\text { point } 8 \text { Shaytanka } \\
\text { river, below } \\
\text { discharge }\end{array}$ & 7.1 & 0.02 & 0.02 & 0.5 & 0.02 & 10 \\
\hline \multicolumn{7}{|c|}{ Levikhinsky mine } \\
\hline $\begin{array}{c}\text { point } 14 \text { mine } \\
\text { waters }\end{array}$ & 3.6 & 17.5 & 175 & 1225 & 65.5 & 6938 \\
\hline $\begin{array}{c}\text { point } 15 \text { mine } \\
\text { waters }\end{array}$ & 2.9 & 7.2 & 109 & 161 & 42.4 & 3525 \\
\hline
\end{tabular}




\begin{tabular}{|c|c|c|c|c|c|c|}
\hline $\begin{array}{c}\text { point 16 discharge } \\
\text { in the Tagil river }\end{array}$ & $\mathbf{4 . 6}$ & $\mathbf{5 . 7}$ & $\mathbf{8 5}$ & $\mathbf{5 8}$ & $\mathbf{3 5 . 5}$ & $\mathbf{2 5 9 6}$ \\
\hline $\begin{array}{c}\text { point 17 Tagil } \\
\text { river, above } \\
\text { discharge }\end{array}$ & 7.4 & $\mathbf{0 . 0 2}$ & $\mathbf{0 . 0 5}$ & $\mathbf{0 . 7}$ & 0.07 & 35 \\
\hline $\begin{array}{c}\text { point 18 Tagil } \\
\text { river, below } \\
\text { discharge }\end{array}$ & 7.1 & $\mathbf{0 . 1 4}$ & $\mathbf{1 . 9}$ & $\mathbf{1 . 4}$ & $\mathbf{1 . 2}$ & $\mathbf{1 4 6}$ \\
\hline
\end{tabular}

Notes. Exceeded MAC are highlighned in bold

The MAC overrun factor increases downstream up to 8 for copper and up to 4 in iron (Table 3). overrun factor increases to 8 for copper and to 4 in iron 4 (Table 3). Some dead copper-sulphide mines are located in the Tagil river valley. These are Lomovsky, Karpushikhinsky, and Levikhinsky mines. The MAC value of all the components is exceeded by several hundred and thousand times in the mine waters. The MAC of several components decreases significantly after processing by technogenic water treatment plants. Thus, after the Krestyanka river outlet to the Tagil river with treated drain waters from the Lomovsky mine the MAC overrun factor decreased three-fold for zinc, 20 times for copper and 7 times for iron.

At discharge of treated mine waters from Karpushikhinsky mine to the Shaytanka river the MAC drops in zinc, iron and copper by 2, 5 and 20 times, respectivly. In spite of dilution, the volume in water in the Tagil river after discharge of treated mine waters does not comply with regulatory requirements established for water bodies of commercial fishing importance: 29 times higher for copper, 7 times for iron, and 5-8 times higher for zinc (Table 3).

After discharge of treated mine waters from Levikhinsky mine the concentration of components in the Tagil river increases for iron, copper and zinc by 2, 7, and 38 times, respectively. The manganese and sulfate MAC is also 4 and 17 times higher, although no increased concentration of those components was observed upstream.

Miny waters treatment degree at flooded Lomovsky, Karpushikhinsky, and Levikhinsky mines amounts to $98-99 \%$ for copper, zinc and iron, and $95-97 \%$ manganese and sulfates (Table 3). Nevertheless, component concentrations at the outlet from Levikhinsky mine to Tagil river exceed the MAC considerably: by 5600 and 8500 times for copper and zinc, and by 640 and 350 times for iron and manganese (Fig. 3).

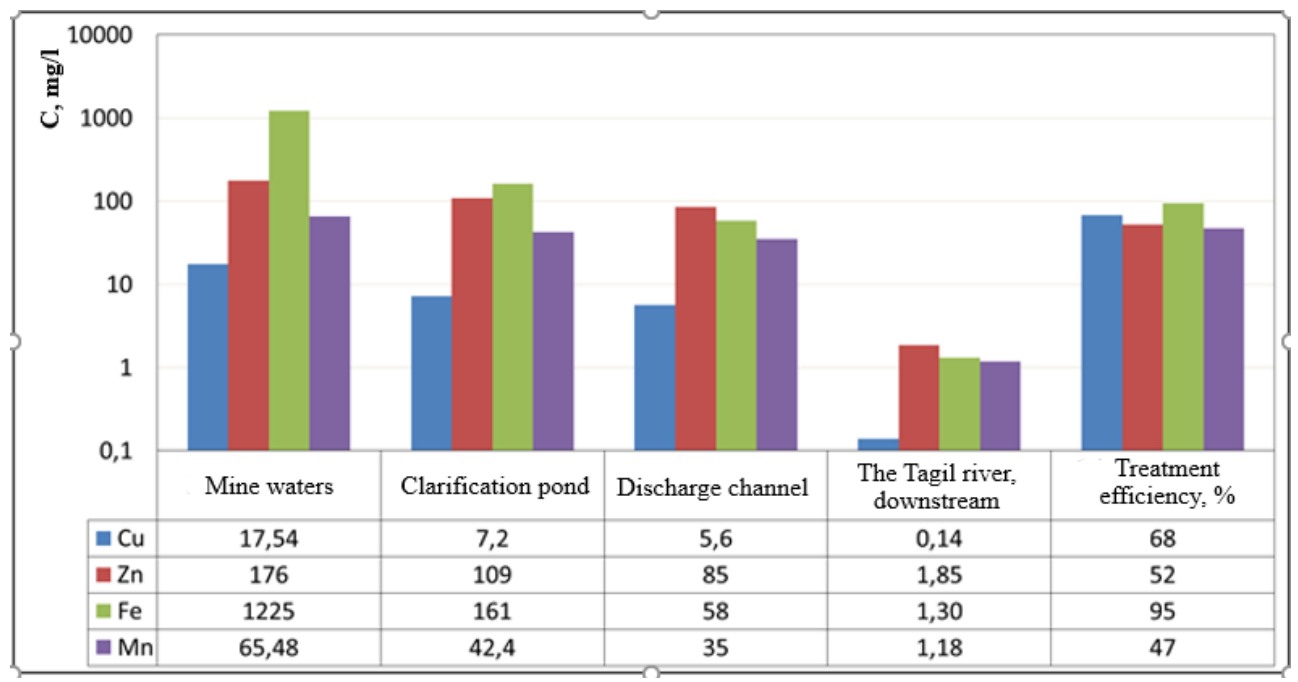


Fig. 3. Changes of contaminant concentration in the Levikhinsky mine area water bodies (average values over 2019)

Measures to minimize the impact of acid mine waters discharged by copper-sulphide mines on the hydrosphere of the Tagil river upper reaches. Low efficiency of treatment at flooded Levikhinsky mine arises out of the whole variety of reasons. Firstly, initial concentrations in mine waters of Levikhinsky mine are much higher (35 and 159 with regard to zinc and iron) than concentration of the same components in mine waters of the Lomovsky mine. Secondly, the flowrate of untreated mine waters at Levikhinsky mine amounts to about 3,000 $\mathrm{m}^{3} /$ day, which is $10-20$ higher than at Karpushikhinsky mine and at Lomovsky mine. Thirdly, the reach of Levikha river channel from point of discharge of treated mine waters from settling pond to its offing stretches for $1.4 \mathrm{~km}$, while the river channel is straightened in its bottom part, as a result of which, the water flows too quickly after settling and ends up in Tagil river, having not enough time for joining complete reaction with alkaline agents during re-neutralization. The length of reach after discharge of treated mine waters at Lomovsky and Karpushikhinsky mines amounts to $3.5 \mathrm{~km}$, the Krestyanka and Shaytanka river channels have moderately circuitous course, as a result, water flows slowly, which results in sufficient reaction with applied alkaline agents. Fourthly, even though clarification pond area is the largest one at Levikhinsky mine (142 ha vs. 10 ha at Lomovsky mine), this volume is not sufficient for complete setting after neutralization.

To increase efficiency of mine water treatment within Levikhinsky mine the existing active system should be augmented with components of passive treatment. To this end, an open lime channel can be designed, which is a quite inexpensive structure yet has a capacity to decrease the acid load effectively. In addition, linked small ponds need to be arranged over the straightened stretch of the Levikha river channel. This will ensure deposition of metals due to reduced water flow rate and longer time of reaction of contaminants with the agents [12].

\section{Conclusions}

Pollution of the Tagil river is a consequence of a few emerging factors. First, these are natural factors, since the background concentrations of copper and zinc are 4-5 times higher than MAC in the upper reaches of the river already. Secondly, these are technologically induced factors whose impact results in generation of acid mine waters over a long time even after abandonment of the copper-sulphide mines. It takes decades and even hundreds of years for the hydrosphere of mining areas at post-development stage, to rehabilitate itself, i.e. the period within which the concentration of the main contaminants (copper, zinc, iron, manganese) decreases to maximum acceptable or background values is so long. Thirdly, these are technological factors connected with imperfections of used methods of treatment of acid mine waters. To increase efficiency of mine water treatment the existing active system should be augmented with components of passive treatment. An open lime channel which has a capacity to decrease the acid load can be used to this end. In addition, linked small ponds need to be arranged over the straightened stretch of the Levikha river channel. This will ensure deposition of metals due to reduced water flow rate and longer time of contaminants reaction with the agents. 


\section{Acknowledgements}

The studies have been accomplished in terms of The Fundamental Research Program of the Russian Academy of Sciences, topics 0405-2019-0005 and 0328-2019-005 as per the research plan for 2019-2021.

\section{References}

1. A.V Khokhryakov, A.F. Fadeichev, E.M .Tseytlin, Inzynieria Mineralna, 15, 283-285 (2014)

2. V.A. Dauwalter, M.V. Dauwalter, N.V. Saltan, E.N. Semenov, Geochemistry, 6, 628646 (2009)

3. Phuong Thao Dang, Vu Chi Dang, E3S Web of Conferences, 35 (2018)

4. URL: http://ele-spb.ru/main/?q=node/22

5. Lorax Environmental (INAP), 129 (2003)

6. URL: https://projects.exeter.ac.uk/geomincentre/estuary/Main/jane.htm

7. J. Relvas, Á. Pinto, J. Matos, SGA News 31, 1-19 (2012)

8. M.D. Reeder, T.D Branam, G.A. Olyphant, Proc. 27th Ann. Meeting of the ASMR, 813$827(2010)$

9. R.S. Hedin, R.W. Nairn, R.L.P. Kleinmann, USDI, Bureau of Mines Information Circular IC 9389, 34 (1994)

10. A. Alcolea, M. Vázquez, A. Caparrós, I. Ibarra, C. García, R. Linares, R. Rodríguez, Minerals Engineering, 26, 86-98 (2012)

11. A. Jarvis, A. England, Uranium in the Aquatic Environment, 1019-1026 (2002)

12. L.S. Rybnikova, P.A. Rybnikov, V.Yu. Navolokina, Subsurface management, 3(22), 155-161 (2019)

13. L.S. Rybnikova, P.A.Rybnikov, Geochemistry International, 57 (3), 298-313 (2019)

14. Water quality standards applied to water bodies of commercial fishing importance, including standards specifying maximum permissible concentrations of harmful substances in waters of water bodies of commercial fishing importance (M.: VNIRO Press 2011) 